\title{
Tropical seaways played a more important role than high latitude seaways in Cenozoic cooling
}

\author{
Z. Zhang ${ }^{1,2}$, K. H. Nisancioglu ${ }^{1}$, F. Flatøy ${ }^{1}$, M. Bentsen ${ }^{1}$, I. Bethke ${ }^{1}$, and H. Wang ${ }^{2}$ \\ ${ }^{1}$ Bjerknes Centre for Climate Research, UniResearch, 5007, Bergen, Norway \\ ${ }^{2}$ Nansen-Zhu International Research Center, Institute of Atmospheric Physics, Chinese Academy of Sciences, \\ 100029, Beijing, China
}

Received: 15 March 2011 - Published in Clim. Past Discuss.: 21 March 2011

Revised: 23 June 2011 - Accepted: 28 June 2011 - Published: 26 July 2011

\begin{abstract}
Following the Early Eocene climatic optimum (EECO, 55-50 Ma), climate deteriorated and gradually changed the earth from a greenhouse into an icehouse, with major cooling events at the Eocene-Oligocene boundary ( $\sim 34 \mathrm{Ma})$ and the Middle Miocene ( $\sim 15 \mathrm{Ma})$. It is believed that the opening of the Drake Passage had a marked impact on the cooling at the Eocene-Oligocene boundary. Based on an Early Eocene simulation, we study the sensitivity of climate and ocean circulation to tectonic events such as the closing of the West Siberian Seaway, the deepening of the Arctic-Atlantic Seaway, the opening of the Drake Passage, and the constriction of the Tethys and Central American seaways. The opening of the Drake Passage, together with the closing of the West Siberian Seaway and the deepening of the Arctic-Atlantic Seaway, weakened the Southern Ocean Deep Water (SODW) dominated ocean circulation and led to a weak cooling at high latitudes, thus contributing to the observed Early Cenozoic cooling. However, the later constriction of the Tethys and Central American Seaways is shown to give a strong cooling at southern high latitudes. This cooling was related to the transition of ocean circulation from a SODW-dominated mode to the modern-like ocean circulation dominated by North Atlantic Deep Water (NADW).
\end{abstract}

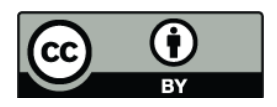

Correspondence to: Z. Zhang (zhongshi.zhang@bjerknes.uib.no)

\section{Introduction}

The Cenozoic Era was a period of long-term cooling, with major cooling events at the Eocene-Oligocene boundary and the Middle Miocene (e.g., Miller, 1992; Zachos et al., 2001; Liu et al., 2009). There are several hypotheses trying to explain the mechanisms behind the Cenozoic cooling (e.g., Kennett, 1977; Raymo and Ruddiman, 1992; DeConto and Pollard, 2003; Coxall et al., 2005). One hypothesis is that past reorganizations of ocean circulation could have been an important factor. Among the tectonic events that had an impact on ocean circulation, the opening of the Drake Passage is thought to have contributed to cooling at the EoceneOligocene boundary. The opening of the Drake Passage enabled the development of the Antarctic Circumpolar Current (ACC), which thermally insulated Antarctica through reduced southward heat transport (e.g., Toggweiler and Bjornsson, 2000; Nong et al., 2000; Sijp and England, 2004), and also influenced the formation of deep water in the North Atlantic (NADW) (Toggweiler and Bjornsson, 2000; Scher and Martin, 2008).

This thermal isolation hypothesis is, however, in conflict with recent studies (Livermore et al., 2005; Scher and Martin, 2006; Lagabrielle et al., 2009) indicating that the opening of the Drake Passage might have been much earlier than the Eocene-Oligocene boundary. Further, modelling studies have demonstrated that the change of ocean heat transport with the opening of the high latitude seaways was weak (Huber and Nof, 2006), and the cooling caused by the changes in ocean heat transport is insignificant compared to the cooing caused by the drop of atmospheric $\mathrm{CO}_{2}$ levels (DeConto and Pollard, 2003).

Published by Copernicus Publications on behalf of the European Geosciences Union. 
The warm greenhouse climate of the Early Eocene marked the beginning of the long term Cenozoic cooling trend, and has been the focus of several recent modelling studies (Huber et al., 2004; Heinemann et al., 2009; Roberts et al., 2009; Shellito et al., 2009; Tindall et al., 2010; Winguth et al., 2010; Speelman et al., 2010; Lunt et al., 2010). These studies have tested the sensitivity of climate to a large increase in atmospheric greenhouse gases (Shellito et al., 2009; Winguth et al., 2010; Lunt et al., 2010), explored the mechanism behind the Arctic warming (Heinemann et al., 2009; Shellito et al., 2009), simulated the isotope distribution of ancient seawater and precipitation in the Early Eocene (Tindall et al., 2010, Speelman et al., 2010), and also considered the possible climatic effects caused by the changes to the high latitude seaways, including the West Siberian Seaway, AtlanticArctic Seaway (Roberts et al., 2009), Drake Passage and Tasman Seaway (Huber et al., 2004). However, the impact of tropical seaways on the warm Early Eocene climate has not been addressed in detail. More importantly, under the Early Eocene land-sea configuration, with a narrow and shallow Drake Passage and a narrow Tasman Seaway, the ACC was relatively weak (Huber and Sloan, 2001; Zhang et al., 2010), challenging the thermal isolation hypothesis which requires the development of a strong ACC once the Drake Passage opens.

Here, starting from a simulation of Early Eocene climate, we use FOAM (Fast Ocean Atmosphere Model) (Jacob et al., 2001) to examine the climate sensitivity to changes in the seaways, including the closing of the West Siberian Seaway, the deepening of the Arctic-Atlantic Seaway, the opening/deepening of Drake Passage and in particular the constriction of the tropical Atlantic seaways: the Tethys Seaway and the Central American Seaway.

In this paper, Sect. 2 introduces the climate model FOAM and the experimental design. Sections 3 and 4 present the Early Eocene control experiment and four sensitivity experiments with changes in the most important seaways. Section 5 compares the simulations with geological evidence and previous modelling studies, and discusses the implications of this study for understanding Cenozoic cooling. A summary follows in Sect. 6.

\section{Model and experimental design}

\subsection{Model introduction}

FOAM version 1.5 is a fully coupled General Circulation Model (GCM), run without flux corrections (Jacob et al., 2001). FOAM consists of a parallel version of the Community Climate Model (CCM2) (Hack et al., 1993), with atmospheric physics upgraded following CCM3.6 (Kiehl et al., 1996). The atmospheric model is run with a horizontal resolution of R15 ( $4.5 \times 7.5$ degrees) and 18 vertical levels. The Ocean Model (OM3) is a finite-difference, $z$-coordinate ocean model with a horizontal resolution of $1.4 \times 2.8$ degrees, 24 vertical levels, and a free surface. The basic equations solved in OM3 are the same as those for the Modular Ocean Model (MOM) (Bryan, 1969; Cox, 1984), and it uses Richardson-number-based vertical mixing. The basic land model in FOAM is a simplified version of the default land model of CCM2 (Hack et al., 1993). The sea ice model uses the thermodynamics of the NCAR CSM Sea Ice Model (Bettge et al., 1996).

FOAM is intended for long century-scale integrations. It provides a good simulation of the mean and variability of the modern climate (e.g., Liu and Wu, 2004). It has also been used in paleoclimate studies of the Holocene (e.g., Liu et al., 2000) and Pleistocene (e.g., Lee and Poulsen, 2006), as well as periods from the deep geological time, such as the Neoproterozoic snowball Earth (Poulsen et al., 2001), Mesozoic paleoclimate and paleoceanography (Poulsen and Huynh, 2006; Donnadieu et al., 2007). Details on the FOAM model can be found here: http://www.mcs.anl.gov/research/ projects/foam/.

\subsection{Boundary conditions}

In the Paleocene/Earliest Eocene, the Arctic connected with the Atlantic by the shallow Atlantic-Arctic Seaway, and with the Tethys Sea via the West Siberian Seaway (e.g., Scotese, 2001). At the same time the Drake Passage closed. However, there was a direct passage between the Pacific and Atlantic through the Central America Seaway. Reorganizations of these seaways occurred gradually. In the Middle Eocene, the West Siberian Seaway closed (Akhmet'ev and Beniamovski, 2006), and the Arctic-Atlantic Seaway deepened by the extension of the Mid-Atlantic Ridge (e.g., Scotese, 2001). Although age estimates for the opening of the Drake Passage are still under debate (Barker, 2001; Lagabrielle et al., 2009), there is evidence indicating an early shallow opening in the Early Eocene (Livermore et al., 2005) and subsequent deepening at $\sim 41 \mathrm{Ma}$ in the Middle Eocene (Scher and Martin, 2006). If this is the case, the opening/deepening of the Drake Passage is simultaneous with the closing of the West Siberian Seaway and the deepening of the Arctic-Atlantic Seaway.

Changes to the tropical seaways occurred later. The narrowing of the Tethys Seaway (Barrier and Vrielynck, 2008) and the Central American seaway (e.g., Droxler et al., 1998) commenced in the Late Eocene. Further gradual shoaling of the Central American seaway began at $\sim 16 \mathrm{Ma}$ (e.g., Droxler et al., 1998), and the Tethys seaway was permanently closed at about $15 \mathrm{Ma}$ (Rögl, 1999).

The Early Eocene boundary conditions (Fig. 1) are set following the paleogeography of Scotese (2001) and the paleobathymetry is estimated using the method outlined by Bice et al. (1998). The paleogeography contains the reconstructions of mountains, coastlines and shallow ocean basins, as well as magnetic lines on the ocean floor. The coastlines outlined by 

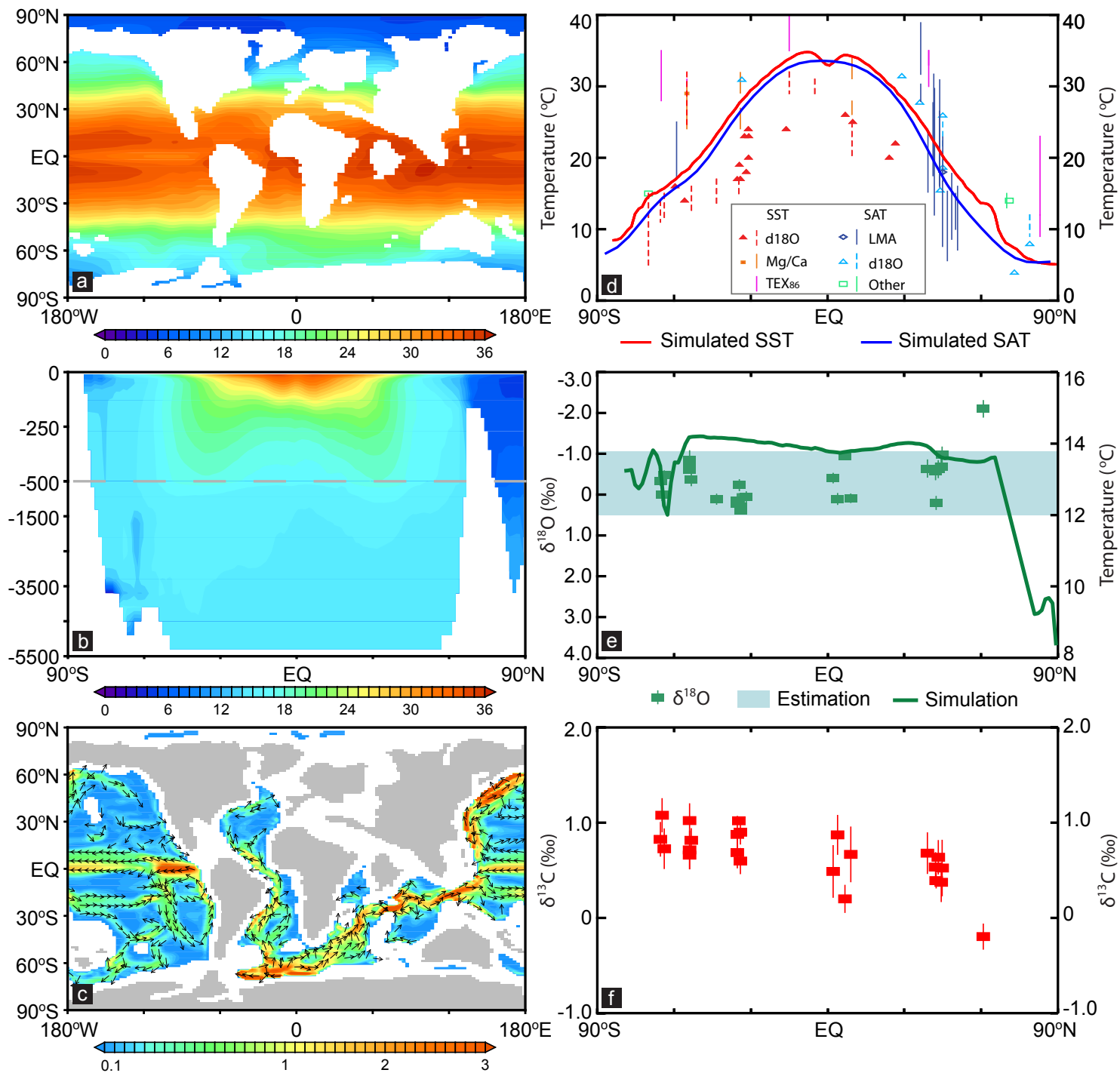

Fig. 1. Warm climate and SODW-dominated ocean circulation simulated in the Early Eocene (EECO) experiment. (a) Sea surface temperature (SST, $\left.{ }^{\circ} \mathrm{C}\right)$. (b) Zonal mean ocean temperature $\left({ }^{\circ} \mathrm{C}\right)$. (c) Deep ocean circulation $\left(\mathrm{cm} \mathrm{s}^{-1}\right)$ at $2500 \mathrm{~m}$. Arrows show flow directions, and colour scales show current speed. (d) Comparison of latitudinal sea surface temperature between the model simulation and proxy records. LMA means leaf-margin analysis. (e) Comparison of deep water temperature among the simulation (bold green line), paleotemperature estimation (green shaded bar) (Lear et al., 2000) and benthic foraminiferal $\delta^{18} \mathrm{O}$ (small green markers). (f) Latitudinal gradients of benthic foraminiferal $\delta^{13} \mathrm{C}$ in the Early Eocene. All geological data used here are listed in the supplementary materials.

Scotese (2001) are set at $0 \mathrm{~m}$, and the shallow ocean basins are given a depth of $200 \mathrm{~m}$. The age-depth relationships established by Bice et al. (1998) are used to calculate the depth of each magnetic line. Finally, this depth data is interpolated into a global areal configuration.

Starting from the reconstructed Early Eocene bathymetry, the main seaways discussed above are changed in the sensitivity experiments (Table 1, Supplement). The West Siberian Seaway is closed in experiment WSSC. The Arctic Atlantic Seaway is deepened in experiment AASD, giving a maximum depth of $1900 \mathrm{~m}$, and an Arctic with a water depth between $2000 \mathrm{~m}$ to $3000 \mathrm{~m}$. The Drake Passage is deepened to about $2500 \mathrm{~m}$ in experiment DPGD. The Tethys Seaway is fully closed and the Central American Seaway is narrowed in experiment TSCN, as the tectonic changes to these two seaways happened close in time. The changes of these two seaways are simplified; however paleogeographical reconstructions (Droxler et al., 1998; Rögl, 1999) illustrate the complicated evolution of the Tethys and Central American Seaway.

In order to focus on the climatic effects caused by changes to the seaways, other boundary conditions are kept fixed. In all experiments, the solar constant and orbital parameters are set to present conditions; vegetation on land is prescribed as shrubland/grassland; and the concentration of atmospheric 


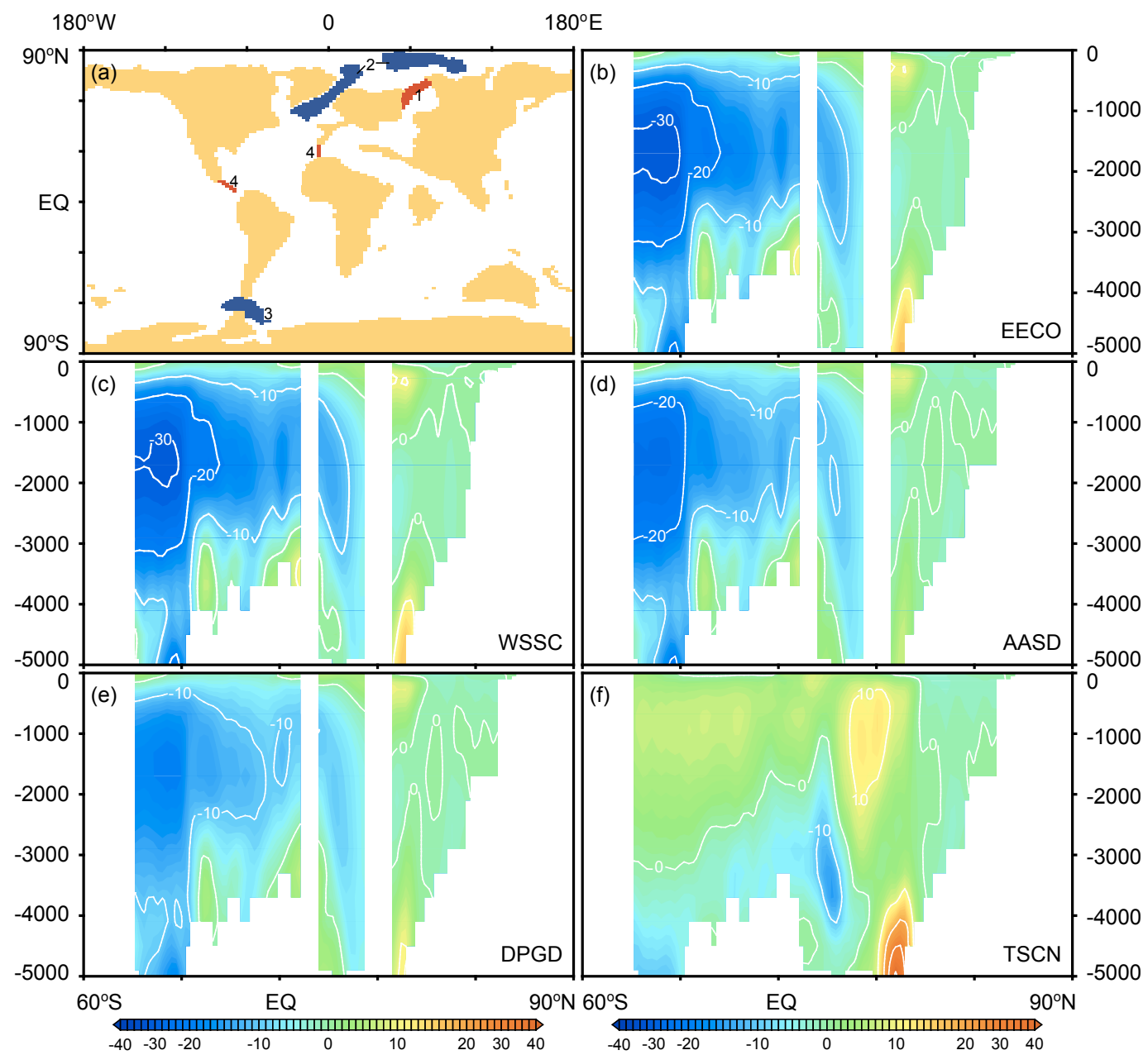

Fig. 2. Atlantic meridional overturning streamfunction (Sv) simulated in the experiments. (a) Early Eocene land-sea distribution (land is yellow) with changes in seaways highlighted in blue and red. (1) closing of the West Siberian Seaway (WSSC); (2) deepening of the Arctic/Arctic-Atlantic Seaway (AASD); (3) deepening of the Drake Passage Gateway (DPGD); (4) constriction of the tropical Atlantic seaways (TSCN), with a fully closed Tethys seaway and narrow Central American seaway. Simulation in the control (b) EECO and the sensitivity experiments (c) WSSC, (d) AASD, (e) DPGD, (f) TSCN.

Table 1. Summary of boundary conditions.

\begin{tabular}{lll}
\hline Exp. & Topography and bathymetry & Other boundary condition \\
\hline Control Run & & Fixed in all experiments: \\
EECO & $50 \mathrm{Ma}$ & Insolation:present solar \\
Sensitivity Experiments & constant and orbital parameters; \\
WSSC & $50 \mathrm{Ma}+$ West Siberian Seaway closing (WSSC) & Vegetation: shrubland everywhere; \\
AASD & $50 \mathrm{Ma}+$ WSSC+Arctic/Arctic-Atlantic Seaway deepening (AASD) & Greenhouse gases: $2240 \mathrm{ppmv} \mathrm{CO}_{2}$, \\
DPGD & $50 \mathrm{Ma}+$ WSSC+AASD+Drake Passage Gateway deepening (DPGD) & $760 \mathrm{ppb} \mathrm{CH}_{4}, 270 \mathrm{ppb}_{2} \mathrm{O}$ \\
TSCN & $50 \mathrm{Ma}+$ WSSC+AASD+DPGD+Tropical seaways closing/narrowing & \\
\hline
\end{tabular}

$\mathrm{CO}_{2}$ is set to 8 times the preindustrial level, following estimates for the Early Eocene (Royer, 2006). This is done to better isolate the roles of the seaways.

\subsection{Initial conditions and model spin-up}

In order to reduce the spin up time we use geological evidence (e.g., Lear et al., 2000; Tripati et al., 2003; Sluijs et al., 2006; Pearson et al., 2007) to construct an initial 
temperature field for the ocean model. We prescribe the temperatures at four points, SST of $34^{\circ} \mathrm{C}$ at the equator, deepwater temperature of $12^{\circ} \mathrm{C}$ at the equator, SST of $15^{\circ} \mathrm{C}$ at both poles and deep-water temperature of $10^{\circ} \mathrm{C}$ at both poles. Based on a rough empirical relationship of present day ocean temperature with depth, we use the following equations: $t_{0}(d)=12+22 \times e^{-\frac{d}{1000}}$ and $t_{90}(d)=10+5 \times e^{-\frac{d}{1000}}$ to calculate the temperature in each layer at the equator and poles. $d$ here is the depth of each layer in the ocean model. Then, a trigonometric sine function is used to set the meridional temperature gradient for each layer, with the temperature difference between the equator and the pole being the amplitude of the sine function. Finally, the meridional ocean temperature profile is applied at all longitudes, giving a threedimensional temperature field to initialize the model.

The EECO experiment is spun up for $1250 \mathrm{yr}$ in a fully coupled configuration, in order to reach equilibrium not only at the ocean surface but also in the deep ocean. After the 1250 yr spin-up, we continue the EECO experiment to model year 2000. We use the 1250 of the spin-up to initialize the four sensitivity experiments. These sensitivity experiments run for another $750 \mathrm{yr}$ to reach quasi-stationary ocean states. All results reported here are the averages of the last $100 \mathrm{yr}$ of each experiment.

\section{The Early Eocene simulation}

The Early Eocene experiment simulates a warm climate and an ocean circulation dominated by Southern Ocean Deep Water (SODW). The global mean surface air temperature (SAT) is $25^{\circ} \mathrm{C}$, and the global mean sea surface temperature (SST) is $27^{\circ} \mathrm{C}$ (Fig. 1). The average SST in the Arctic basin is about $6{ }^{\circ} \mathrm{C}$ and in the Southern Ocean about $15^{\circ} \mathrm{C}$. SODW divides into two branches: one flows north in the Atlantic and upwells in the tropics; the other branch flows through the Indian Ocean and upwells in the Pacific.

Reconstructions of surface temperature for the Early Eocene are based on oxygen isotope data (e.g., Zachos et al., 1994; Schmitz et al., 1996; Fricke and Wing, 2004; Eldrett et al., 2009), Ma/Ca ratios (e.g., Tripati et al., 2003) and the TEX $_{86}$ method (a paleothermometer based on the distribution of crenarchaeotal membrane lipids) (Sluijs et al., 2006; Brinkhuis et al., 2006; Bijl et al., 2009; Hollis et al., 2009). They give a rough estimate of the zonal mean surface temperature gradient during the Early Eocene. The simulated zonal mean SAT and SST fall within the range of the reconstructed temperature gradient (Fig. 1d).

It is important to note the uncertainties in these reconstructions of surface temperature. The reconstructions of SST have uncertainties due to the choice of oxygen isotopic composition of mean seawater, the estimated $\mathrm{Mg} / \mathrm{Ca}$ of seawater, and the calibration of $\mathrm{TEX}_{86}$ (Huber, 2008). The recent SST reconstructions based on oxygen isotopes (e.g., Pearson et al., 2007; Ivany et al., 2008) are warmer than the earlier results (Zachos et al., 1994). The SST estimates based on
TEX $_{86}$ (Sluijs et al., 2006, 2007; Brinkhuis et al., 2006; Bijl et al., 2009; Hollis et al., 2009) appear to be warmer than those from oxygen isotopes and $\mathrm{Mg} / \mathrm{Ca}$. Most of the terrestrial temperature estimates, even though they are mostly from North America (e.g., Fricke and Wing, 2004; Greenwood et al., 2005), show a large range.

The simulated surface air temperature falls within the range of terrestrial temperature estimates. The simulated sea surface temperature agrees better with the most recent estimates based on $\mathrm{Mg} / \mathrm{Ca}$ and oxygen isotopes (e.g., Tripati et al., 2003; Pearson et al., 2007; Ivany et al., 2008), but is significantly lower than the estimates based on $\mathrm{TEX}_{86}$, both at low and high latitudes. The model-data discrepancy appears in the northern high latitudes, particularly in the Arctic. The simulated surface temperature is about $5 \sim 6{ }^{\circ} \mathrm{C}$ at the surface in the northern high latitudes, which agrees well with other simulations with the same atmospheric $\mathrm{CO}_{2}$ level (Shellito et al., 2009). However, the simulated annual mean temperatures at northern high latitudes are still lower than most proxy based estimates which fall within the range 10 to $15^{\circ} \mathrm{C}$ (Eberle et al., 2010).

In the deep ocean (Fig. 1e), the simulated temperature is consistent with the estimated range of $\sim 12-14{ }^{\circ} \mathrm{C}$ based on $\mathrm{Mg} / \mathrm{Ca}$ ratios (Lear et al., 2000). Since the Early Eocene simulation presented here has reached equilibrium, the biases in model-data comparison of deep ocean temperature should be small. The simulated Early Eocene ocean circulation is supported by the reconstruction of circulation based on $\delta^{13} \mathrm{C}$ ratios from benthic foraminifera (Fig. 1f), which indicates active deep water formation in the Southern Hemisphere and its northward flow (aging) (Nunes and Norris, 2006).

\section{The sensitivity experiments}

In the sensitivity experiments starting from the Early Eocene control climate (EECO), two types of overturning circulation can be discriminated: one dominated by the formation of SODW and the other by NADW (Fig. 2). As in the control simulation, SODW continues dominating ocean circulation in the experiments with a closed West Siberian Seaway (WSSC), a deep Arctic-Atlantic Seaway (AASD), and a deep Drake Passage (DPGD). However, the intensity of SODW formation is weakened, with a maximum overturning at about $40^{\circ} \mathrm{S}$ reduced from $31 \mathrm{~Sv}$ in the control run (EECO) to $20 \mathrm{~Sv}$ in experiment DPGD. Once the tropical seaways (the Tethys and Central American Seaway) are closed/narrowed in experiment TSCN, the deep ocean circulation changes drastically with the commencement of deepwater formation in the North Atlantic and the dominance of NADW (Figs. 2f and 3b).

With the transition to a NADW-dominated ocean circulation in experiment TSCN, global mean SST is reduced by about $0.4{ }^{\circ} \mathrm{C}$ compared to the Early Eocene control climate (EECO). In contrast to the nearly symmetric cooling in the high latitudes of both hemispheres in experiment DPGD, the 

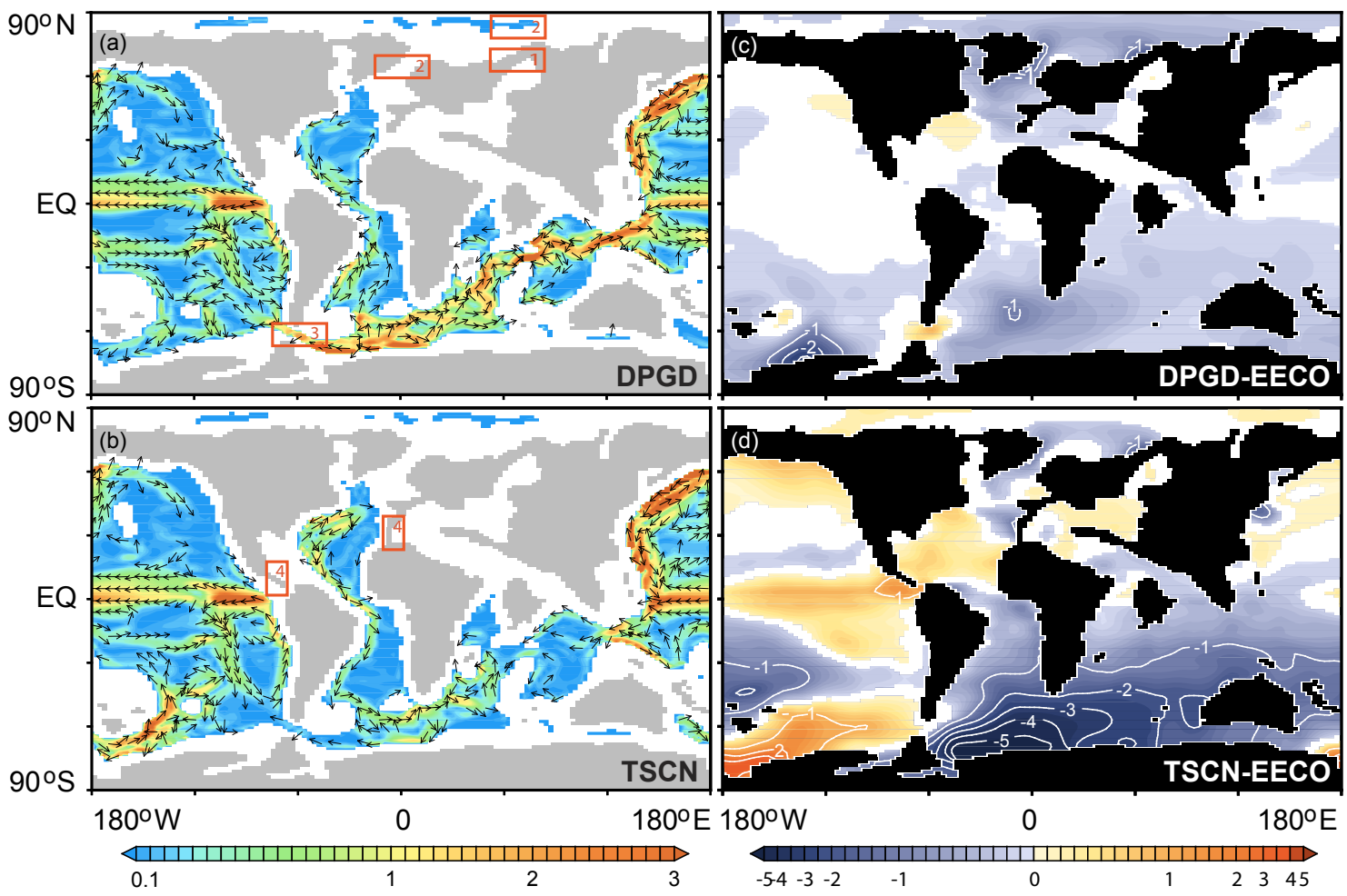

Fig. 3. Transition of ocean circulation from a SODW-dominated to a NADW-dominated mode and its impact on SST. Deep ocean currents $\left(\mathrm{cm} \mathrm{s}^{-1}\right)$ at $2500 \mathrm{~m}$ for experiments (a) DPGD and (b) TSCN. Geographic distributions of SST changes $\left({ }^{\circ} \mathrm{C}\right)$ in the DPGD (c) and the TSCN (d) experiments, compared to the control experiment (EECO). Arrows show flow directions, and colour scales show current speed. Changes in seaways are highlighted by red rectangles: (1) closing of the West Siberian Seaway (WSSC); (2) deepening of the Arctic/Arctic-Atlantic Seaway (AASD); (3) deepening of the Drake Passage Gateway (DPGD); (4) constriction of the tropical Atlantic seaways (TSCN), with a fully closed Tethys seaway and narrow Central American seaway. The statistical signifcance has been tested with the t-test, based on annual mean SST time series for each point. Only SST changes with confidence levels greater than $95 \%$ are illustrated here.

cooling in experiment TSCN is focused to the East Antarctic section of the Southern Ocean (Fig. 3d). A significant decrease of surface air temperature is also observed over East Antarctica (not shown). Note that the initiation of Antarctic glaciation at the Eocene-Oligocene boundary and the expansion at the Middle Miocene were focused to East Antarctica (Zachos et al., 2001). No cooling can be observed over West Antarctica, on which the glaciation occurred later in the Late Miocene (Zachos et al., 2001).

The pattern of the SST changes is similar to the familiar sea-saw pattern (Crowley, 1992), with a strong cooling in the South Atlantic and a warming in the North Atlantic. The sea-saw pattern is best seen when comparing the TSCN and DPGD experiments (Fig. 4a).

A similar pattern of changes in sea surface salinity (SSS) is observed in response to the closed/narrowed tropical seaways. SSS increases by 2 psu in the North Atlantic, and decreases $\sim 2$ to $4 \mathrm{psu}$ in the South Atlantic (Fig. 4b). At the same time, the western boundary currents along the east coast of Southern American are strengthened (Fig. 4c).

The above changes of SSS and currents are caused by the reduction in transport through the Tethys and Central Amer- ica Seaways. Due to the salinity of inflowing Indian Ocean water feeding the Tethys Sea, the salinity in the Tethys Sea is lower than in the tropical and subtropical North Atlantic in the EECO experiment. After the tropical seaways are narrowed/closed in the sensitivity experiments, the flow of water through these two seaways is reduced, particularly in experiment TSCN (Table 2). The closing of the Tethys Seaway shuts down the relatively fresh surface current that flows into the North Atlantic, increasing SSS in the subtropical North Atlantic. Similarly, the narrowing of the Central American Seaway reduces the inflow of relatively fresh Pacific water and supports the development of the western boundary current in the Atlantic. The change of the surface salinity and currents in the Atlantic, caused by the reduced inflow from the Pacific and Tethys Sea, is beneficial for the commencement of NADW formation.

In the sensitivity experiments dominated by SODW formation, there are only small changes in meridional heat transport. Compared with the control run (EECO), experiments WSSC, AASD and DPGD show very small changes in ocean heat transport (Fig. 5). 


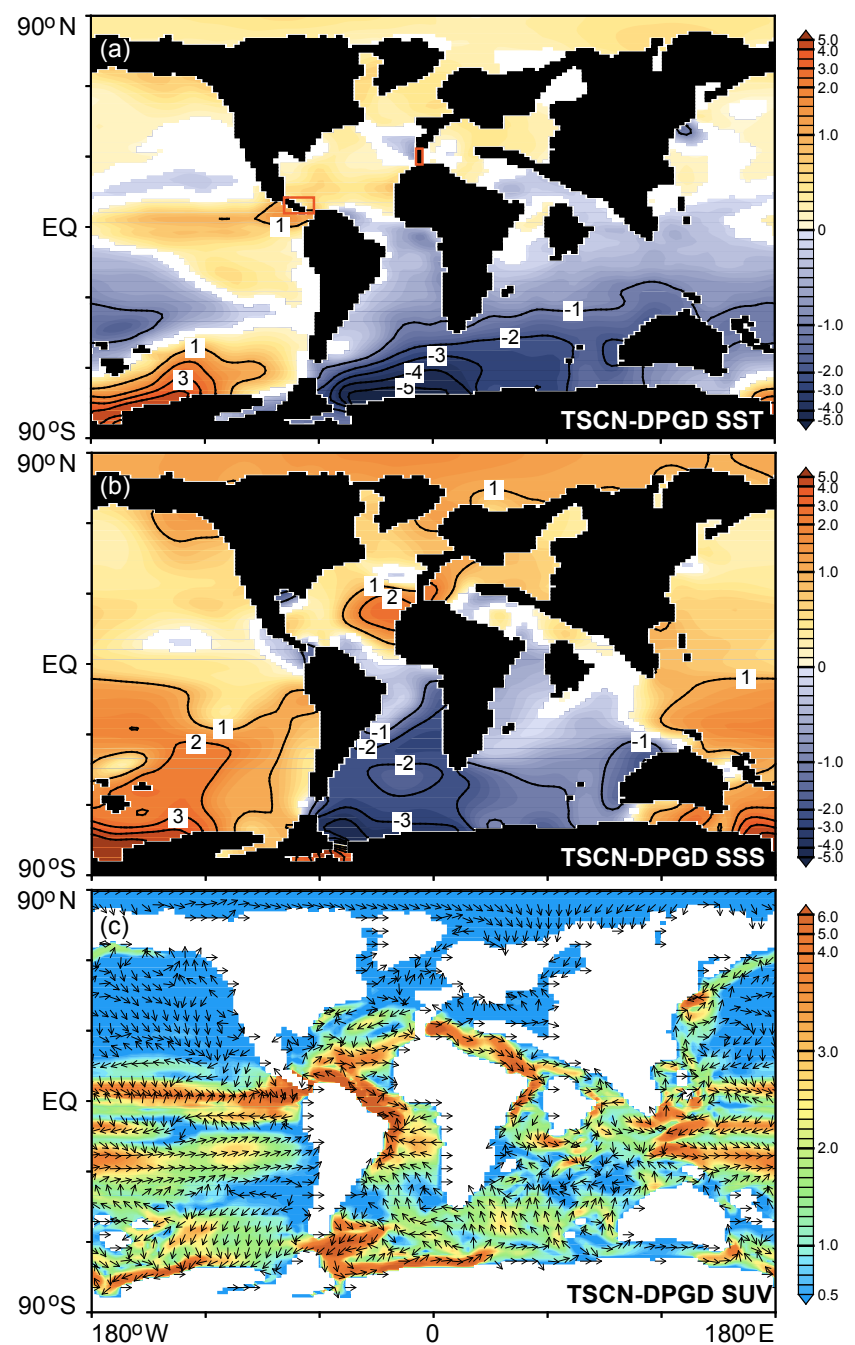

Fig. 4. Geographic changes of (a) SST $\left({ }^{\circ} \mathrm{C}\right)$, (b) SSS and (c) sur-

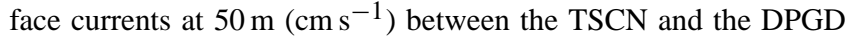
experiment. SST and SSS changes with confidence levels greater than $95 \%$ are illustrated in (a) and (b). The two red rectangles in (a) highlight the Central American Seaway (Left) and the section of the Tethys Seaway (Right) for calculating water mass in Table 2.

Table 2. Water mass (Sv) transport through the Tethys Seaway and the Central American Seaway. Positive values are to the east.

\begin{tabular}{lrr}
\hline Exp. & Tethys seaway & Central American Seaway \\
\hline EECO & -4.56 & 9.40 \\
WSSC & -4.55 & 8.83 \\
AASD & -4.54 & 6.27 \\
DPGD & -4.33 & 3.62 \\
TSCN & 0 & 1.04 \\
\hline
\end{tabular}

However, once a NADW-dominated ocean circulation is established in experiment TSCN, northward heat transport is intensified, particularly in the Atlantic (Fig. 5c). As a result, there is a cooling in the Southern Hemisphere (Fig. 6). Although there is a strong cooling over parts of the Southern Ocean, simulated surface temperatures remain above freezing, and the area of sea ice does not increase. Due to the production of deep water in the North Atlantic, more heat is transported from the surface to the deep ocean (Fig. 6c and d).

\section{Discussion}

\subsection{The role of tropical seaways}

The simulated surface temperature gradient and ocean circulation agrees well with previous modelling studies (Shelltio et al., 2009; Winguth et al., 2010). Further, the comparison to proxy data illustrates that the experiment EECO simulates the Early Eocene climate reasonably well, although our simulation can not reproduce the full magnitude of the reconstructed Early Eocene warming in the Arctic region.

Here, we focus on the important role of tropical seaways in the evolution of Cenozoic ocean circulation and climate. Starting from a realistic Early Eocene simulation, the sensitivity experiments indicate that the transition in ocean circulation has a cooling effect on southern high latitudes. The constriction of the main tropical Atlantic seaways appears to play a leading role in this transition. Earlier modelling studies with a shallow Central American Seaway and a closed Tethys Seaway show the existence of NADW in the South Atlantic (Nisancioglu et al., 2003), a strong cooling in the Southern Hemisphere (von der Heydt and Dijkstra, 2006) and development of a western boundary current in the Atlantic (Omta and Dijkstra, 2003). All these studies show that the NADW dominated ocean circulation exists with the Central American Seaway fully opened, suggesting that the Tethys Seaway is more important for the transition of ocean circulation.

The role of the Tethys Seaway is supported by the timing of key geological events (Fig. 7). Detailed reconstructions of the paleogeography (Rögl, 1999) illustrate that the Tethys Seaway was open in the early Miocene ( 24-19 Ma), closed in the late early Miocene ( 19-17 Ma), opened again in the middle Miocene $(\sim 17-15 \mathrm{Ma})$, before it permanently closed at about $15 \mathrm{Ma}$. The reduced carbon isotope gradient between the Atlantic and Pacific indicates that NADW formation was active during a period in the late early Miocene and dominated ocean circulation again after about $15 \mathrm{Ma}$ (Wright et al., 1992), though this may be complicated by lower oceanic nutrient levels. Oxygen isotope data reveal that climate was warm in the earliest Miocene, followed by a relatively cold period in the late early Miocene, then came the warm middle Miocene Climate Optimum, and finally 

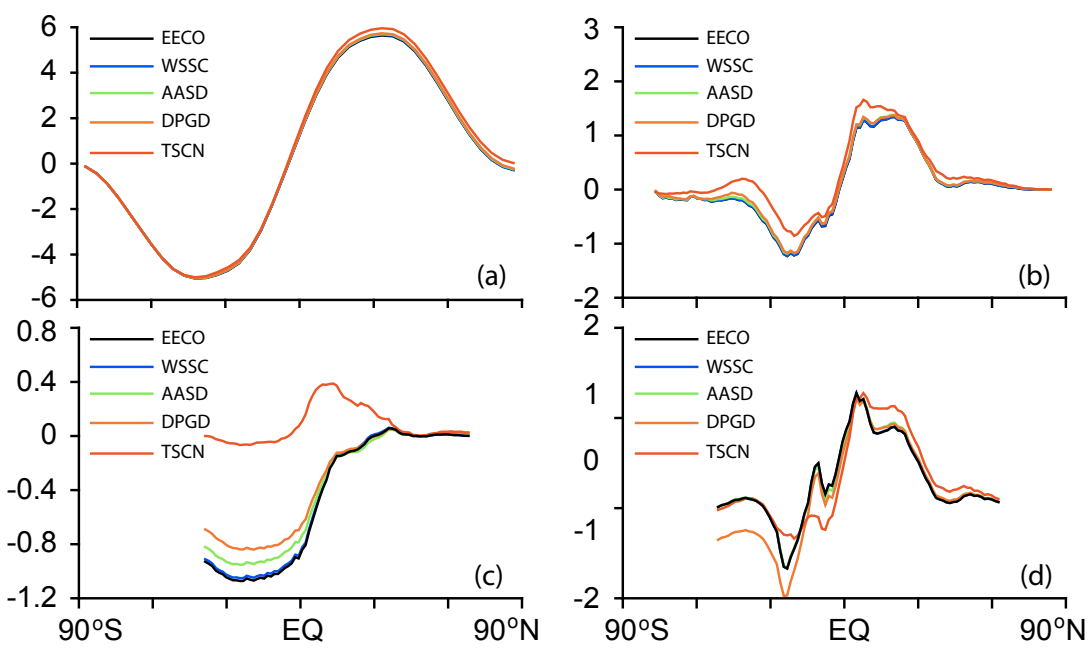

Fig. 5. Heat transports in the EECO (black), WSSC (blue), AASD (green), DPGD (orange) and TSCN (red), (a) total heat transport, (b) ocean heat transport for all ocean basins, (c) Atlantic heat transport, (d) Pacific heat transport.

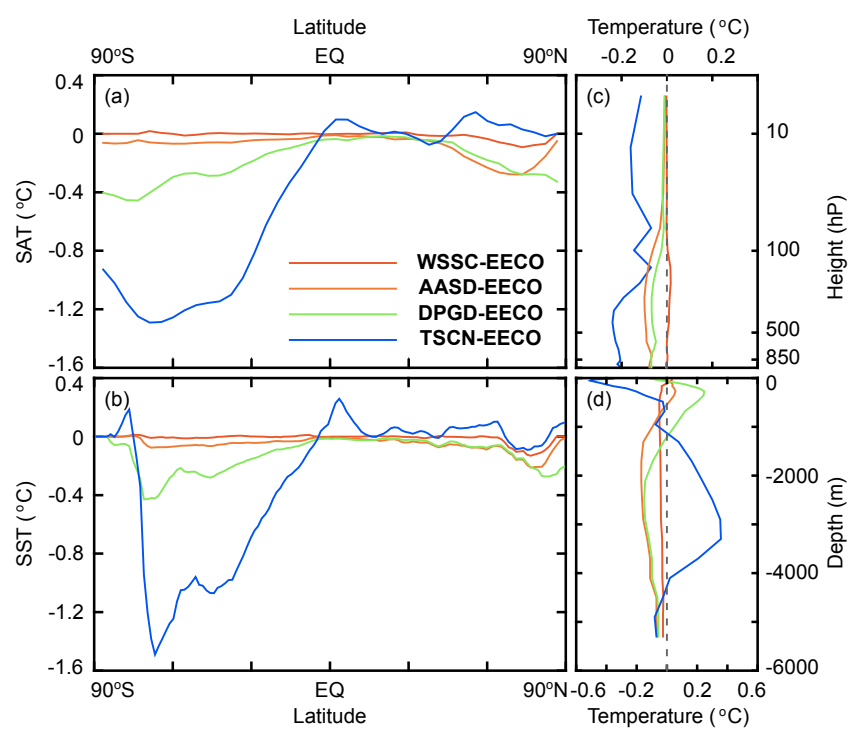

Fig. 6. Changes in atmosphere and ocean temperature $\left({ }^{\circ} \mathrm{C}\right)$ in the four sensitivity experiments. (a) Zonal mean SAT anomaly. (b) Zonal mean SST anomaly. (c) Changes of global mean atmosphere temperature with height. (d) Changes of global mean ocean temperature with depth.

the establishment of a ice-sheet on East Antarctica ( 15$14 \mathrm{Ma}$ BP) (Zachos et al., 2001, 2008). These events show that stages with a closed (open) Tethys Seaway correspond well to active (inactive) NADW formation and a cold (warm) climate, supporting the results simulated here. In addition to the Tethys Seaway, the gradual shoaling of the Central American Seaway beginning $\sim 16 \mathrm{Ma}$ contributed to the transition of ocean modes and the consequent cooling in the Miocene. Note also that the Tethys Seaway is important for the devel- opment of the monsoon climate in East Asia (Ramstein et al., 1997; Zhang et al., 2007a, b).

The earliest evidence of NADW formation has been found in deep sea cores from the Early Oligocene (Davies et al., 2001; Via and Thomas, 2006; Scher and Martin, 2008). This is approximately the time when the Arabia-Eurasia collision happened (Allen and Armstrong, 2008). The collision might have caused notable narrowing of the Tethys Sea, though the sea was still open in the Oligocene (Rögl, 1999). Simulations of Oligocene climate (von der Heydt and Dijkstra, 2008) suggest that NADW formation could have existed before the Tethys Seaway permanently closed. Therefore, the timing for the onset of NADW is still under debate, and the two candidates are the Early Oligocene and the Middle Miocene. However, both of these two time periods start with a cooling.

In an earlier study, with an idealized model investigating the role of the tropical seaways, Hotinsky and Toggweiler (2003) found that the closing of a Tethyan circumglobal passage caused a cooling of the Northern Hemisphere. This is in contradiction to our results showing a warming of the Northern Hemisphere when the tropical seaways are constricted. This difference is most likely due to the very different model configurations. The previous study used a highly idealized bathymetry, or "water planet" with strong wind-driven upwelling in the tropics, and did not realistically simulate salinity changes caused by fresh water input associated with changes to the land-sea distribution. As our simulations demonstrate, the increase of sea surface salinity is one important reason for the transition of ocean circulation to the NADW mode associated with warming in the Northern Hemisphere.

The simulations indicate that the role of the Drake Passage opening/deepening on ocean circulation and climate is less important compared to the impact of the Tethys and Central 


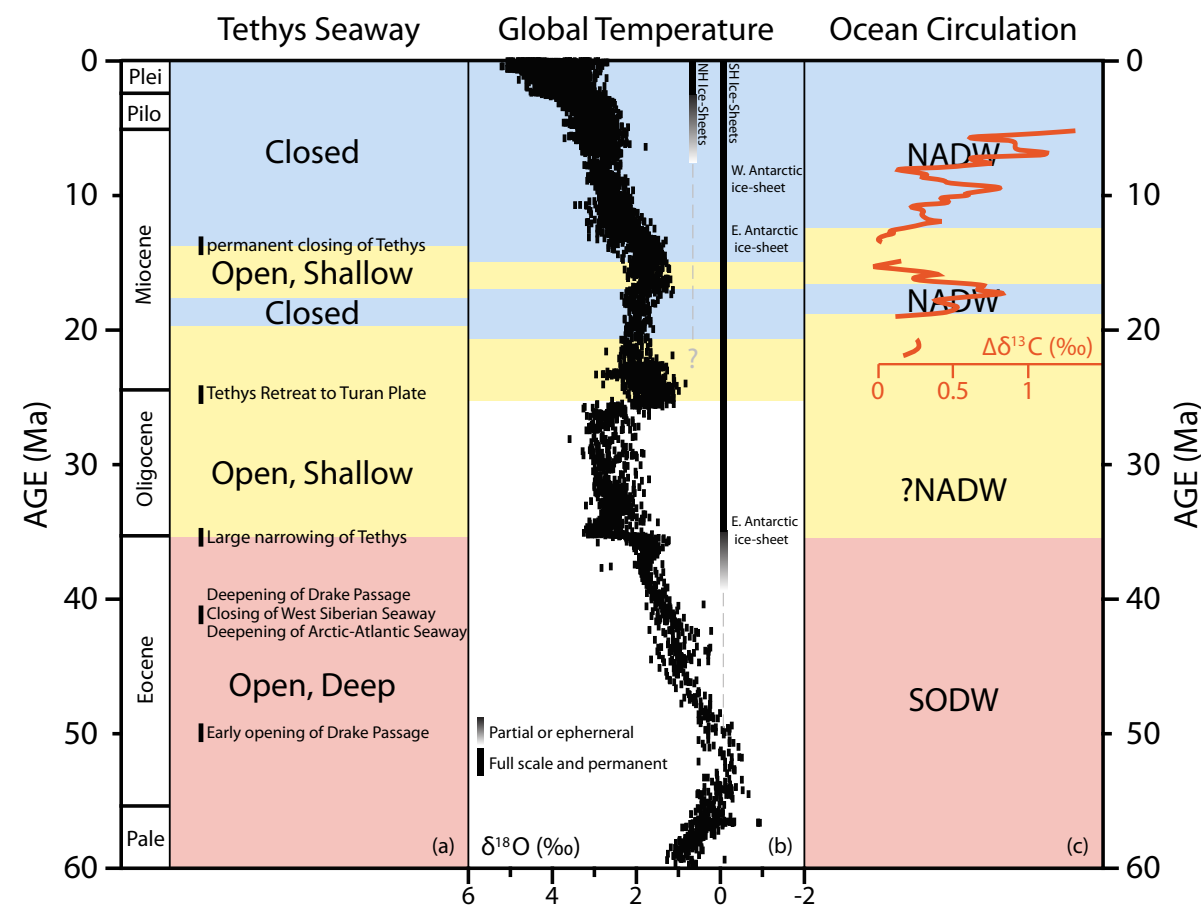

Fig. 7. Timing of key geological events, (1) the evolution of the Tethys Seaway, (2) Cenozic cooling based on deep-sea oxygen isotopes and ice-sheet development (Zachos et al., 2001, 2008), (3) the evolution of ocean circulation. The Tethys evolution is summarized according to Akhmet'ev and Beniamovski (2006), Rögl (1996), Barrier and Vrielynck (2008). The changes of other seaways are summarized according to Scotese (2001), Livermore et al. (2005) and Scher and Martin (2006). The Early Oligocene evidence of NADW formation is summarized according to Davies et al. (2001), Via and Thomas (2006) and Scher and Martin (2008). The red line shows the NADW index based on benthic carbon isotopes (Wright et al., 1992). The high value of $\Delta \delta^{13} \mathrm{C}$ indicates active NADW, and the low value indicates inactive NADW.

American Seaways. These results challenge the prevailing hypothesis that the Drake Passage is the key player in major cooling events during the Cenozoic and the glaciation of Antarctica.

The cooling effect of the Drake Passage and its impact on Cenozoic glaciations might have been overestimated in the earlier sensitivity experiments (e.g., Nong et al., 2000; Sijp and England, 2004), as they were carried out with present topography and bathymetry. In this case, the intensity of the Antarctic Circumpolar Current (ACC) is above $100 \mathrm{~Sv}$, once the Drake Passage is opened. However, as shown in the present study, the Drake Passage was relatively narrow and shallow in the early Cenozoic, and ocean circulation was dominated by the formation of SODW. As a consequence, the ACC during the early Cenozoic is thought to have been significantly weaker than present (Huber and Sloan, 2001; this study). With this in mind, the effect of the Drake Passage on ocean circulation and the climate of Antarctica during the early Cenozoic should be reconsidered.

\subsection{Implications for Cenozoic cooling}

The mechanisms behind the long term Cenozoic cooling trend and major cooling events are still under debate. There are four main hypotheses/theories, including the thermal iso- lation of Antarctica (Kennett, 1977; Toggweiler and Bjornsson, 2000), declining levels of atmospheric $\mathrm{CO}_{2}$ (DeConto and Pollard, 2003; Huber and Nof, 2006), uplift of large mountains (Raymo and Ruddiman, 1992), and modified insolation patterns and seasonality (Coxall et al., 2005). The thermal isolation hypothesis for understanding the cooling at the Eocene-Oligocene boundary has been challenged by geological evidence (Moran et al., 2006; Tripati et al., 2008), early modelling studies (DeConto and Pollard, 2003; Huber and Nof, 2006) and the present study. The $\mathrm{CO}_{2}$ theory suggests that the declining levels of atmospheric $\mathrm{CO}_{2}$ is more important in understanding the cooling at the EoceneOligocene boundary. This theory is strongly supported by reconstructions of Cenozoic atmospheric $\mathrm{CO}_{2}$ (e.g., Pagani et al., 2005; Zachos et al., 2008, Pearson et al., 2009) and modelling studies (DeConto and Pollard, 2003; Huber and Nof, 2006). However, this does not answer the question why atmospheric $\mathrm{CO}_{2}$ levels decreased greatly during the Cenozoic, and in particular at the Eocene-Oligocene boundary. The uplift hypothesis links mountain uplift with the drop of atmospheric $\mathrm{CO}_{2}$ levels in the Cenozoic (Raymo and Ruddiman, 1992). The uplift of the Himalayas-Tibetan Plateau, Rocky Mountains and Andes Mountains would increase chemical weathering, thereby reducing atmospheric 
$\mathrm{CO}_{2}$ levels and cause a cooling. This hypothesis is still important in understanding the long-term cooling trend in the Cenozoic. However, there are uncertainties in the history of the uplift, and it is difficult to estimate how much atmospheric $\mathrm{CO}_{2}$ was removed in the process. The weak insolation hypothesis suggests that weak insolation caused by the Earth's orbital configuration was the ultimate trigger for the cooling events at the Eocene-Oligocene boundary (Coxall et al., 2005). However, this hypothesis is based on a tuned age model, with its inherent uncertainties (Kuiper et al., 2008). In summary, the key remaining problem in explaining the Cenozoic cooling is why atmospheric $\mathrm{CO}_{2}$ levels were greatly reduced, in particular at the Eocene-Oligocene boundary.

In the present study, our experiments illustrate the linkage between tropical seaways and ocean circulations associated with the Cenozoic cooling. The constriction of the main tropical Atlantic seaways appears to play an important role in the transition of ocean circulation from a SODW to a NADW ocean circulation mode. The transition of ocean circulations causes a significant cooling in the Southern Hemisphere. We suggest that this linkage is potentially important for understanding the Cenozoic cooling, in particular for the cooling at the Eocene-Oligocene boundary.

However, there are still some limitations in our present study. In order to better isolate the role of the seaways, we carry out the experiments with the atmospheric $\mathrm{CO}_{2}$ level fixed at eight times the preindustrial level. Due to the high atmospheric $\mathrm{CO}_{2}$ level, we are limited to address the possible impact of the decrease in atmospheric $\mathrm{CO}_{2}$ levels on ocean circulations. As earlier studies illustrated, the changes of atmospheric $\mathrm{CO}_{2}$ level may also influence ocean circulation modes (Lunt et al., 2010), and climate sensitivities to seaways associated with different atmosphere $\mathrm{CO}_{2}$ levels can be different (Sijp et al., 2009). Furthermore, we do not distinguish the respective roles of the Central American Seaway and the Tethys Seaway. Based on the Early Eocene land-sea distribution conditions, we are not able to consider the possible influence of the widening of the Atlantic on the meridional overturning circulation (von der Heydt and Dijkstra, 2008). With these limitations in mind, the linkage between the tropical seaways and the ocean circulations still needs to be tested by more experiments with reduced atmospheric $\mathrm{CO}_{2}$ levels.

In our experiments, the local cooling in the Southern Hemisphere caused by the transition from a SODW to a NADW dominated ocean circulation is significant (Figs. 3d and $6 a, b)$. However, the global effect of the transition is minimal, with a global mean cooling of $0.4{ }^{\circ} \mathrm{C}$ in SST. The global cooling is weaker than what is estimated from available geological evidence (e.g., Liu et al., 2009; Eldrett et al., 2009), indicating that changes in ocean circulation alone can not fully explain the cooling at the Eocene-Oligocene boundary. Additional factors must be involved to account for the full scale of the cooling, such as the drop of atmospheric $\mathrm{CO}_{2}$ levels (DeConto and Pollard, 2003; Huber and Nof, 2006).
Here, we suggest the potential link between the transition of ocean circulation from a SODW to a NADW dominated mode and the large observed drop in atmospheric $\mathrm{CO}_{2}$ levels at the Eocene-Oligocene boundary. Since the ocean plays a vital role in the Earth's carbon cycle, it is likely that the transition of ocean circulation to a NADW dominated mode might have played an important role in causing the drop in atmospheric $\mathrm{CO}_{2}$ levels in the Cenozoic. The response of the carbon cycle can be very fast (e.g., Dunkley et al., 2010). Further improving our knowledge of the link between ocean circulation and the carbon cycle is important for understanding the cooling pattern at the surface (Liu et al., 2009), the debate of bipolar versus polar glaciation (DeConto et al., 2008; Lear et al., 2008), and extinction and environmental events (Pearson et al., 2008) at the Eocene-Oligocene boundary. However, how the switch from a SODW to a NADW dominated mode of circulation impacted the carbon cycle remains an open question, which must be addressed by additional proxy data and modelling studies.

Although the simulations presented here and the studies of DeConto and Pollard (2003), Huber et al. (2004) and Huber and Nof (2006) indicate that the Drake Passage plays a minor role in cooling the Antarctic continent, the impact of the Drake Passage opening/deepening on the long-term Cenozoic cooling trend should not be neglected. With a gradual expansion and deepening of the Drake Passage, the strength of the ACC is expected to have increased, possibly, playing a role in the observed long-term global cooling in the Cenozoic.

\section{Summary}

In summary, starting from an equilibrium simulation of the Early Eocene, the important role of tropical seaways is highlighted in the present study. The simulation shows a potential important linkage between tropical seaways and the Cenozoic cooling. The Cenozoic cooling trend was enhanced by the transition between two different ocean circulation modes: one corresponding to a SODW-dominated mode and the other to a NADW-dominated mode. The closing of the Tethys Seaway was likely to be key to the transition from the SODW to the NADW. The constriction of the Tethys Seaway and the establishment of modern-like ocean circulation dominated by NADW formation might have triggered the Eocene-Oligocene cooling and glaciation over Antarctica, once atmospheric $\mathrm{CO}_{2}$ levels reached a critical level. Although the role of the Tethys Seaway is supported by some geological evidence, the role of tropical seaways still needs to be investigated by more modelling and data studies in future. 


\section{Supplementary material related to this article is available online at: http://www.clim-past.net/7/801/2011/ cp-7-801-2011-supplement.pdf.}

Acknowledgements. We sincerely thank Nanne Weber, Gilles Ramstein and Anna von der Heydt for their suggestions and contributions during the revision of the paper. We thank Robert Jacob for technical support on the model. We thank Eystein Jansen, Martin Miles and Thomos Leslie Leith for thoughtful reviews, Yongqi Gao, Jinzhi Su, Xu Yue and Lei Yu for discussions. This work is supported by the National 973 Program of China under Grant 2010CB950102, the National Natural Science Foundation of China under Grant 40902054 and the funding from Statoil, Norway.

Edited by: N. Weber

\section{References}

Akhmet'ev, M. A. and Beniamovski, V. N.: The Paleocene and Eocene in the Russian part of West Eurasia, Stratigr. Geol. Correl., 14(1), 49-72, doi:10.1134/S0869593806010047, 2006.

Allen, M. B. and Armstrong, H. A.: Arabia-Eurasia collision and the forcing of mid-Cenozoic global cooling, Palaeogeogr. Palaeocl., 265, 52-58, 2008.

Barker, P. F.: Scotia Sea regional tectonic evolution: implications for mantle flow and palaeocirculation, Earth Sci. Rev., 55, 1-39, 2001.

Barrier, E. and Vrielynck, B.: Palaeotectonic maps of the Middle East, CGMW, 2008.

Bettge, T. W., Weatherly, J. W., Washington, W. M., Pollard, D., Briegleb, B. P., and Strand, W. G.: The CSM Sea Ice Model. NCAR Technical Note NCAR/TN-425+STR, National Center for Atmospheric Research, Boulder, Colorado, 1996.

Bice, K. L., Barron, E. J., and Peterson, W. H.: Reconstruction of realistic Early Eocene paleobathymetry and ocean GCM sensitivity to specified basin configuration, in: Tectonic Boundary Conditions for Climate Reconstructions, edited by: Crowley, $\mathrm{T}$. and Burke, K., Oxford Univ. Press., 227-247, 1998.

Bijl, P., Schouten, S., Sluijs, A., Reichart, G., Zachos, J. C., and Brinkhuis, H.: Early palaeogene temperature evolution of the southwest pacific ocean, Nature, 461, 776-779, 2009.

Brinkhuis, H., Schouten, S., Collinson, M. E., Sluijs, A., Damste , J. S. S., Dickens, G. R., Huber, M., Cronin, T. M., Onodera, J., Takahashi, K., Bujak, J. P., Stein, R., van der Burgh, J., Eldrett, J. S., Harding, I. C., Lotter, A. F., Sangiorgi, F., Cittert, H. K., de Leeuw, J. W., Matthiessen, J., Backman, J., Moran, K., and the Expedition 302 Scientists: Episodic fresh surface waters in the Eocene Arctic Ocean, Nature, 441, 606-609, doi:10.1038/nature04692, 2006.

Bryan, K.: A numerical method for the study of the circulation of the World Ocean, J. Comp. Phys., 4, 347-376, 1969.

Cox, M. D.: A primitive equation three-dimensional model of the ocean. Technical report GFDL ocean group Tech. Rep. 1, GFDL, Princeton, NJ, 1984.

Coxall, H. K., Wilson, P., Pälike, H., Lear, C. H., and Backman, J.: H Rapid stepwise onset of Antarctic glaciation and deeper calcite compensation in the Pacific Ocean, Nature, 433, 53-57, 2005.
Crowley, T. J.: North Atlantic Deep Water cools the southern hemisphere, Paleoceanography, 7, 489-498, 1992.

Davies, R., Cartwright, J., Pike, J., and Line, C.: Early Oligocene initiation of North Atlantic Deep Water formation, Nature, 410, 917-920, 2001.

DeConto, R. M. and Pollard, D.: Rapid Cenozoic glaciation of Antarctica induced by declining atmospheric $\mathrm{CO}_{2}$, Nature, 421, 245-249, 2003.

Donnadieu, Y., Pierrehumbert, R., Jacob, R., and Fluteau, F.: Modelling the primary control of paleogeography on Cretaceous climate, Earth Planet. Sci. Lett., 248, 426-437, 2006.

Droxler, A. W., Burke, K., Cunningham, A. D., Hine, A. C., Rosencrantz, E., Duncan, D. S., Hallock, P., and Robinson, E.: Caribbean constraints on circulation between Atlantic and $\mathrm{Pa}-$ cific Oceans over the past 40 million years, In: Tectonic Boundary Conditions for Climate Reconstructions, edited by: Crowley, T. and Burke, K., Oxford Univ. Press., 169-191, 1998.

Dunkley Jones, T., Ridgwell, A., Lunt, D. J., Maslin, M. A., Schmidt, D. N., and Valdes, P. J.: A Paleogene perspective on climate sensitivity and methane hydrate instability, Philos. T. R. Soc., 368, 2395-2415, doi:10.1098/rsta.2010.0053, 2010.

Eberle, J. J., Fricke, H. C., Humphrey, J. D., Hackett, L., Newbrey, M. G., and Hutchinson, J. H.: Seasonal variability in Arctic temperatures during early Eocene time, Earth Planet. Sci. Lett., 296, 481-486, 2010.

Eldrett, J. S., Greenwood, D. R., Harding, I. C., and Huber, M.: Increased seasonality through the Eocene to Oligocene transition in Northern high latitudes, Nature, 459, 969-974, doi:10.1038/nature08069, 2009.

Fricke, H. C. and Wing, S. L.: Oxygen isotope and paleobotanical extimates of temperature and $818 \mathrm{O}$-latitude gradients over North America during the Early Eocene, Am. J. Sci., 304, 612-635, 2004.

Greenwood, D. R., Archibald, S. B., Mathewes, R. W., and Moss, P. T.: Fossil biotas from the Okanagan Highlands, southern British Columbia and northeastern Washington State: climates and ecosystems across an Eocene landscape, Can. J. Earth Sci., 42, 167-185, doi:10.1139/E04-100, 2005.

Hack, J. J, Boville, B. A., Briegleb, B. P., Kiehl, J. T., Rasch, P. J., and Williamson, D. L.: Description of the NCAR Community Climate Model (CCM2). NCAR Tech. Note NCAR/TN382+STR, Natl. Cent. Atmos. Res., Boulder, CO, 1993.

Heinemann, M., Jungclaus, J. H., and Marotzke, J.: Warm Paleocene/Eocene climate as simulated in ECHAM5/MPI-OM, Clim Past, 5, 785-802, doi:10.5194/cp-5-785-2009, 2009.

Hollis, C. J., Handley, L., Crouch E. M., Morgans, H. E. G., Baker, J. A., Creech, J., Collins, K. S., Gibbs, S. J., Huber, M., Schouten, S., Zachos, J. C., and Pancost, R. D.: Tropical sea temperatures in the high-latitude South Pacific during the Eocene, Geology, 37(2), 99-102, 2009.

Hotinsky, R. M. and Toggweiler, J. R.: Impact of a Tethyan circumglobal passage on ocean heat transport "and equable" climates, Paleoceanography, 18, 1007, doi:10.1029/2001PA000730, 2003.

Huber, M.: A Hotter Greenhouse?, Science, 321, 353-354, 2008.

Huber, M. and Nof, D.: The ocean circulation in the southern hemisphere and its climatic impacts in the Eocene, Palaeogeogr. Palaeocl., 231, 9-28, 2006.

Huber, M. and Sloan, L. C.: Heat transport, deep waters, and thermal gradients: coupled simulation of an Eocene greenhouse cli- 
mate, Geophys. Res. Lett., 28, 3481-3484, 2001.

Huber, M., Brinkhuis, H., Stickley, C. E., Döös, K., Sluijs, A., Warnaar, J., Schellenberg, S. A., and Williams, G. L.: Eocene circulation of the Southern Ocean: was Antarctica kept warm by subtropical waters?, Paleoceanography, 19, PA4026, doi:10.1029/2004PA001014, 2004.

Ivany, L. C., Lohmann, K. C., Hasiuk, F., Blake, D. B., Glass, A., Aronson, R. B., and Moody, R. M.: Eocene climate record of a high southern latitude continental shelf: Seymour Island, Antarctica, Geol. Soc. Am. Bull., 120, 659-678, 2008.

Jacob, R., Schafer, C., Foster, I., Tobis, M., and Anderson, J.: Computational Design and Performance of the Fast Ocean Atmosphere Model, Version One, in: Proc. 2001 International Conference on Computational Science, edited by: Alexandrov, V. N., Dongarra, J. J., and Tan, C. J. K., Springer-Verlag, 175-184, 2001.

Kennett, J. P.: Cenozoic evolution of Antarctic glaciation, the circum-Antarctic ocean, and their impact on global paleoceanography, J. Geophys. Res., 82, 3843-3859, 1977.

Kiehl, J. T., Hack, J. J., Bonan, G. B., Boville, B. A., Briegleb, B. P., Williamson, D. L., and Rasch, P. J.: Description of the NCAR Community Climate Model (CCM3). NCAR Tech. Note NCAR/TN-420+STR, Natl. Cent. for Atmos. Res., Boulder, CO, 1996.

Kuiper, K. F., Deino, A., Hilgen, F. J., Krijgsman, W., Renne, P. R., and Wijbrans, J. R.: Synchronizing rock clocks of Earth History, Science, 320, 500-504, doi:10.1126/science.1154339, 2008.

Lagabrielle, Y., Goddéris, Y., Donnadieu, Y, Malavieille, J., and Suarez, M.: The tectonic history of Drake Passage and its possible impacts on global climate, Earth Planet. Sci. Lett., 279, 197211, 2009.

Lear, C. H., Elderfield, H., and Wilson, P. A.: Cenozoic deep-sea temperatures and global ice volumes from $\mathrm{Mg} / \mathrm{Ca}$ in benthic foraminiferal calcite, Science, 287, 269-272, doi:10.1126/science.287.5451.269, 2000.

Lear, C. H., Bailey, T. R., Pearson, P. N., Coxall, H. K., and Rosenthal, Y.: Cooling and ice growth across the Eocene-Oligocene transition, Geology, 36, 251-254, 2008.

Lee, S.-Y. and Poulsen, C. J.: Sea ice control of Plio-Pleistocene tropical Pacific climate evolution, Earth Planet. Sci. Lett., 248, 238-247, 2006.

Liu, Z. and Wu, L.: Atmospheric response to the North Pacific SST: The role of ocean-atmosphere coupling, J. Climate, 17, 18591882, 2004.

Liu, Z., Kutzbach, J., and Wu, L.: Modeling Climate Shift of El Nino Variability in the Holocene, Geophys. Res. Lett., 27(15), 2265-2268, 2000.

Liu, Z., Pagani, M., Zinniker, D., DeConto, R., Huber, M., Brinkhuis, H., Shah, S. R., Leckie, R. M., and Pearson, A.: Global cooling during the Eocene-Oligocene climate transition, Science, 323, 1187-1190, 2009.

Livermore, R., Nankivell, A., Eagles, G., and Morris, P.: Paleogene opening of Drake Passage, Earth. Planet. Sci. Lett., 236, 459470, doi:10.1016/j.eps1.2005.03.027, 2005.

Lunt, D. J., Valdes, P. J., Dunkley Jones, T., Ridgwell, A., Haywood, A. M., Schmidt, D. N., Marsh, R., and Maslin, M.: $\mathrm{CO}_{2}$ driven ocean circulation changes as an amplifier of PaleoceneEocene thermal maximum hydrate destabilization, Geology, 38(10), 875-878, doi:10.1130/G31184.1, 2010.
Miller, K. G.: Middle Eocene to Oligocene stable isotopes, climate, and deep-water history: The Terminal Eocene Event?, in: Eocene-Oligocene Climatic and Biotic Evolution, edited by: Prothero, D. and Berggren, W. A., Princeton Univ. Press, 160177, 1992.

Moran, K., Backman, J., Brinkhuis, H., Clemens, S. C., Cronin, T., Dickens, G. R., Eynaud, F., Gattacceca, J., Jakobsson, M., Jordan, R. W., Kaminski, M., King, J., Koc, N., Krylov, A., Martinez, N., Matthiessen, J., McInroy, D., Moore, T. C., Onodera, J., ORegan, M., Pälike, H., Rea, B., Rio, D., Sakamoto, T., Smith, D. C., Stein, R., St John, K., Suto, I., Suzuki, N., Takahashi, K., Watanabe, M., Yamamoto, M., Farrell, J., Frank, M., Kubik, P., Jokat, W., and Kristoffersen, Y.: The Cenozoic palaeoenvironment of the Arctic Ocean, Nature, 441, 601-605, doi:10.1038/nature04800, 2006.

Nisancioglu, K. H., Raymo, M. E., and Stone, P. H.: Reorganization of Miocene deep water circulation in response to the shoaling of the Central American Seaway, Paleoceanography, 18(1), 1006, doi:10.1029/2002PA000767, 2003.

Nong, G. T., Najjar, R. G., Seidov, D., and Peterson, W. H.: Simulation of ocean temperature change due to the opening of the Drake Passage, Geophys. Res. Lett., 27, 2689-2692, 2000.

Nunes, F. and Norris, R. D.: Abrupt reversal in ocean overturning during the Palaeocene/Eocene warm period, Nature, 439, 60-63, doi:10.1038/nature04386, 2006.

Omta, A. W. and Dijkstra, H. A.: A physical mechanism for the Atlantic-Pacific flow reversal in the early Miocene, Glob. Planet. Change, 788, 1-12, 2003.

Pagani, M., Zachos, J. C., Freeman, K. H., Tipple, B., and Bohaty, S.: Marked decline in atmospheric carbon dioxide concentrations during the Paleogene, Science, 309, 600-603, 2005.

Pearson, P. N., van Dongen, B. E., Nicholas, C. J., Pancost, R. D., Schouten, S., Singano, J., and Wade, B. S.: Stable warm tropical climate through the Eocene Epoch, Geology, 35, 211-214, doi:10.1130/G23175A.1, 2007.

Pearson, P. N., McMillan, I. K., Wade, B. S., Dunkley Jones, T., Coxall, H. K., Bown, P. R., and Lear, C. H.: Extinction and environmental change across the Eocene-Oligocene boundary in Tanzania, Geology, 36, 179-182, doi:10.1130/G24308A.1, 2008.

Pearson, P. N., Foster, G. L., and Wade, B. S.: Atmospheric carbon dioxide through the Eocene-Oligocene climate transition, Nature, 461, 1110-1113, 2009.

Poulsen, C. J., Pierrehumbert, R. T., and Jacob, R. L.: Impact of ocean dynamics on the simulation of the Neoproterozoic "snowball earth”, Geophys. Res. Lett., 28(8), 1575-1578, 2001.

Poulsen, C. J. and Huynh, T. T.: Paleoceanography of the Mesozoic Pacific: A perspective from climate model simulations, in: $\mathrm{Pa}-$ leogeography of the North American Cordillera: Evidence For and Against Large-Scale Displacements, edited by: Haggart, J. W., Enkin, R. J., and Monger, J. W. H., Geological Association of Canada, Special Paper, 46, 13-28, 2006.

Ramstein, G., Fluteau, F., Besse, J., and Joussaume, S.: Effect of orogeny, plate motion and land-sea distribution on Eurasian climate change over the past 30 million years, Nature, 386, 788795, 1997.

Raymo, M. E. and Ruddiman, W. F.: Tectonic forcing of late Cenozoic climate, Nature, 359, 177-122, 1992.

Roberts, C. D., LeGrande, A. N., and Tripati, A. K.: Climate sensitivity to Arctic seaway restriction during the early Paleogene, 
Earth Planet. Sci. Lett., 286, 576-585, 2009.

Rögl, F.: Mediterranean and Parateths, facts and hypotheses of an Oligocene to Miocene paleogeography (short overview), Geological Carpathica, 50(4), 339-349, 1999.

Royer, D. L.: $\mathrm{CO}_{2}$-forced climate thresholds during the Phanerozoic, Geochim. Cosmochim. Acta, 70(23), 5665-5675, 2006.

Scher, H. D. and Martin, E. E.: Oligocene deep water export from the North Atlantic and the development of the Antarctic Circumpolar Current examined with neodymium isotopes, Paleoceanography, 23, PA1205, doi:10.1029/2006PA001400, 2008.

Scher, H. D. and Martin, E. E.: Timing and climatic Consequences of the opening of Drake Passage, Science, 312, 428430, doi:10.1126/science.1120044, 2006.

Schmitz, B., Heilmann-Clausen, C., King, C., Steurbaut, E., Andreasson, F. P., Corfield, R. M., and Cartlidge, J. E.: Stable isotope and biotic evolution in the North Sea during the early Eocene: the Albæk Hoved section, Denmark, Geological Society, London, Special Publications, 101, 275-306, 1996.

Scotese, C. R.: Digital Paleogeographic Map Archive on CD-ROM, PALEOMAP Project, Arlington, Texas, 2001.

Shellito, C. J., Lamarque J. F., and Sloan, L. C.: Early Eocene Arctic climate sensitivity to $p \mathrm{CO} 2$ and basin geography, Geophys. Res. Lett., 36, L09707, doi:10.1029/2009GL037248, 2009.

Sijp, W. P. and England, M. H.: Effect of the Drake Passage Throughflow on global climate, J. Phys. Oceanogr., 34, 12541266, 2004.

Sijp, W. P., England, M. H., and Toggweiler, J. R.: Effect of ocean gateway changes under greenhouse warmth, J. Climate, 22, 6639-6652, 2009.

Sluijs, A., Schouten, S., Pagani, M., Woltering, M., Brinkhuis, H., Damsté, J. S. S., Dickens, G. R., Huber, M., Reichart, G.-J., Stein, R., Matthiessen, J., Lourens, L. J., Pedentchouk, N., Backman, J., Moran, K., and the Expedition 302 Scientists: Subtropical Arctic Ocean temperatures during the Palaeocene/Eocene thermal maximum, Nature, 441, 610-613, doi:10.1038/nature04668, 2006.

Sluijs, A., Brinkhuis, H., Schouten, S., Bohaty, S. M., John, C. M., Zachos, J. C., Reichart, G., Damste, J. S. S., Crouch, E. M., and Dickens, G. R.: Environmental precursors to rapid light carbon injection at the Palaeocene/Eocene boundary, Nature, 450, 12181221, 2007.

Speelman, E. N., Sewall, J. O., Noone, D., Huber, M., von der Heydt, A., Damste, J. S., and Reichart, G.-J.: Modeling the influence of a reduced equator-to-pole sea surface temperature gradient on the distribution of water isotopes in the Early/Middle Eocene, Earth Planet. Sci. Lett., 298, 57-65, 2010.

Tindall, J., Flecker, R., Valdes, P., Schmidt, D. N., Markwick, P., and Harris, J.: Modeling the oxygen isotope distribution of ancient seawater using a coupled ocean-atmosphere GCM: Implications for reconstructing early Eocene climate, Earth Planet. Sci. Lett., 292, 265-273, doi:10.1016/j.epsl.2009.12.049, 2010.
Toggweiler, J. R. and Bjornsson, H.: Drake Passage and paleoclimate, J. Quat. Sci., 15, 238-319, 2000.

Tripati, A. K., Delaney, M. L., Zachos, J. C., Anderson, L. D., Kelly, D. C., and Elderfield, H.: Tropical sea-surface temperature reconstruction for the early Paleogene using $\mathrm{Mg} / \mathrm{Ca}$ ratios of planktonic foraminifera, Paleoceanography, 18, 1101, doi:10.1029/2003PA000937, 2003.

Tripati, A. K., Eagle, R. A., Morton, A., Dowdeswell, J. A., Atkinson, K. L., Bahé, Y., Dawber, C. F., Khadun, E., Shaw, R. M. H., Shorttle, O., and Thanabalasundaram, L.: Evidence for Northern Hemisphere glaciation back to $44 \mathrm{Ma}$ from ice-rafted debris in the Greenland Sea, Earth. Planet. Sci. Lett., 265, 112-122, doi:10.1016/j.epsl.2007.09.045, 2008.

Via, R. K. and Thomas, D. J.: Evolution of Atlantic thermohaline circulation: Early Oligocene onset of deep-water production in the North Atlantic, Geology, 34(6), 441-444, doi:10.1130/G22545.1, 2006.

von der Heydt, A. and Dijkstra, H. A.: Effect of ocean gateways on the global ocean circulation in the late Oligocene and early Miocene, Paleoceanography, 21, PA1011, 2006.

von der Heydt, A. and Dijkstra, H. A.: The effect of gateways on ocean circulation patterns in the Cenozoic, Global Planet. Change, 62, 132-146, 2008.

Winguth, A., Shellito, C., Shields, C., and Winguth, C.: Climate response at the Paleocene- Eocene thermal maximum to greenhouse gas forcing-A model study with CCSM3, J. Clim., 23, 2562-2584, doi:10.1175/2009JCLI3113.1, 2010.

Wright, J. D., Miller, K. G., and Fairbanks, R. G.: Early and Middle Miocene stable isotopes: implications for deepwater circulation and climate, Paleoceanography, 7(3), 357-389, 1992.

Zachos, J. C., Stott, L. D., and Lohmann, K. C.: Evolution of early Cenozoic marine temperature, Paleoceanography, 9, 353-387, 1994.

Zachos, J. C., Pagani, M., Sloan, L., Thomas, E., and Billups, K.: Trends, rhythms, and aberrations in global climate 65 Ma to present, Science, 292, 686-693, doi:10.1126/science.1059412, 2001.

Zachos, J. C., Dickens, G. R., and Zeebe, R. E.: An early Cenozoic perspective on greenhouse warming and carbon-cycle dynamics, Nature, 451, 279-283, 2008.

Zhang, Z.-S., Wang, H.-J., Guo, Z., and Jiang, D.: What triggers the transition of palaeoenvironmental patterns in China, the Tibetan Plateau uplift or the Paratethys Sea retreat?, Palaeogeogr. Palaeoclimatol. Palaeoecol., 245, 317-331, 2007 a.

Zhang, Z.-S., Wang, H., Guo, Z., and Jiang, D.: Impacts of tectonic changes on the reorganization of the Cenozoic paleoclimatic patterns in China, Earth Planet. Sci. Lett., 257, 622-634, 2007b.

Zhang, Z.-S., Yan Q., and Wang, H.-J.: Does the Drake Passage play an essentially important role in the Cenozoic Cooling?, Atmos. Ocean. Sci. Lett., 3, 288-292, 2010. 